\title{
LABOR COSTS AND THE SOCIAL DUMPING DEBATE IN THE EUROPEAN UNION
}

\author{
CHRISTOPHER L. ERICKSON and SAROSH KURUVILLA*
}

\begin{abstract}
This study examines the labor cost incentive for capital movement in manufacturing within the European Union, a key aspect of the "social dumping" debate in Western Europe. The authors find that the percentage differences in unit labor costs between the more developed and less developed countries in the Union not only were large in 1980 but actually grew between 1980 and 1986, and separate estimates of compensation and productivity growth rates do not indicate that significant convergence occurred over the remainder of the 1980s. Although these findings apparently confirm that a labor cost incentive for capital mobility does exist, analysis of foreign direct investment data indicates that during the period 1980-88 capital flows to the lower labor cost countries actually were not much larger than capital flows to the higher labor cost countries.
\end{abstract}

$\mathbf{T}$ he recent debate over the North American Free Trade Agreement (NAFTA) in North America parallels the debate that has gone on for some years in the European Union (previously known as the European Community) over the common market. In both cases, many workers and employers in the high-wage country (or countries) fear that they will lose jobs and business as a result of "free trade" with a country in which labor costs and labor standards are much lower, whereas supporters of free trade argue that the costs will be minimal, can be met by one safety net or another, and in any event will be significantly outweighed by the benefits to consumers of a single or common market. The term "social dumping" has been used to denote the outcomes disadvantageous to labor that many argue could result from the operation of the single market under circum- stances of wide differences in labor standards and costs. This paper examines one key aspect of the social dumping debate: the incentives for capital to move from high labor cost countries to countries with low labor costs.

*Christopher L. Erickson is Assistant Professor, Anderson Graduate School of Management, U.C.L.A., and Sarosh Kuruvilla is Assistant Professor, New York State School of Industrial and Labor Relations, Cornell University. The authors thank the U.S. Bureau of Labor Statistics for providing unpublished compensation data. For advice and comments on earlier drafts of this paper, they also thank Jeffrey Frieden, C. Keith Head, Sanford Jacoby, Edward Leamer, Daniel J.B. Mitchell, Deborah Swenson, and Lowell Turner, as well as participants in seminars at U.C.L.A. and U.C. Berkeley. Financial support was provided by the U.C.L.A. Institute of Industrial Relations and the Cornell Institute for Collective Bargaining. 
The fear that capital flight from highercost countries to lower-cost countries would result in a general depression of labor standards and protections throughout the Union led to the adoption of the Social Charter by eleven of the twelve European Union (EU) countries (Britain dissenting) in December 1989. The Social Charter aims to counteract social dumping via longterm "upward harmonization" of labor standards and social policies.

The Social Charter tends to focus, however, on the differences in labor standards among member countries irrespective of differences in productivity. Yet, inter-country differences in unit labor costs, or worker compensation per unit of output, are more relevant to the capital mobility aspect of the social dumping debate. Labor costs can be a key component of competitive strategy, and it seems doubtful that harmonization policies will be able to equalize the currently large differences in manufacturing labor costs across the EU countries. In the context of the importance attached to labor standards and social protection, the relative lack of attention to labor costs is surprising.

Everyone acknowledges that there are indeed significant differences among EU countries in wages and fringe benefits. In 1992, for example, hourly compensation costs for workers in manufacturing ranged in U.S. dollars from $\$ 25.94$ in Germany to $\$ 5.01$ in Portugal. Yet, Flanagan (1993) has shown that despite the removal of barriers to intra-Union labor mobility over the course of the $1960 \mathrm{~s}$, migration within the Union increased very little during the period 1957-89, and the level of wage dispersion in manufacturing and construction among the original six EU countries in 1989 was only slightly below the level in 1957.

Flanagan's study of wage differentials looked at labor mobility rather than capital mobility. Supporters of unfettered free trade, however, argue that wage comparisons can produce misleading projections of capital mobility, because higher productivity in the high-wage countries may offset most or all of the wage difference-and thus free trade will offer little if any incentive for capital flight. To date, however, no study has empirically evaluated that claim for the EU.

The best labor cost predictor of capital mobility is unit labor costs, because this is the measure that is relevant for employer profit maximization. This study estimates differentials in unit labor costs in manufacturing within the $\mathrm{EU}$ in the most recent year for which all the data are available (1986); we also examine whether these differentials remained stable over the 1980s. We also briefly explore, through an analysis of data that are at best only suggestive, the extent to which capital was already flowing during the 1980s toward the EU countries in which unit labor costs are the lowest.

\section{Social Dumping and the Social Charter}

As Mosely (1990:160) explained,

Social dumping could take place in at least three different ways: (a) through the displacement of high-cost producers by low-cost producers from countries in which wages, social benefits, and direct and indirect costs entailed by protective legislation are markedly lower; (b) firms in high labor cost countries would be increasingly free to relocate their operations, thereby strengthening their bargaining power vis-à-vis their current work force to exert downward pressure on wages and working conditions; and (c) individual states might be tempted to pursue a low wage and perhaps anti-union labor market strategy as part of their efforts to catch up economically. ${ }^{1}$

The general expectation is that the first two types of mechanisms (that is, displacement or movement from high-cost to low-cost countries, or the use of the threat of such

\footnotetext{
${ }^{1}$ The term "social dumping" is also sometimes used to refer to the movement of workers from lowwage countries to high-wage countries. For example, Streeck (1991) discussed the possibility of immigration of unskilled workers to Germany with the elimination of barriers on the free movement of people within the EU. As previously noted, however, Flanagan (1993) found that migration within the EU failed to respond to the reduction of legal barriers to migration since the 1957 Treaty of Rome, even though the wage incentive for out-migration from the low-wage countries was higher in 1988 than in the early 1960 s.
} 
movement as a means of lowering costs in high-cost countries) are the most probable means by which social dumping will occur in the EU.

Such fears led to support for the introduction of a Social Charter, which has been the subject of intense debate. ${ }^{2}$ Such a charter was first explicitly proposed by Jacques Delors, president of the European Commission, in May 1988. In December 1989, the final version of the Social Charter, a substantially diluted version of earlier drafts, was accepted in principle by 11 of the $12 \mathrm{EU}$ countries, with Britain dissenting. Briefly, the Charter is aimed at harmonizing labor protection and social policies across member states via proposals regarding freedom of movement; employment and (minimum) remuneration; improvements of living and working conditions; social protection; freedom of association and collective bargaining; vocational training; equal treatment for men and women; information, consultation, and participation of employees in management; health, protection, and safety at the workplace; and protection of children, adolescents, the elderly, and disabled persons. The draft action program that was intended to be used to develop realistic objectives in respect to the matters in the Charter contains 49 different proposals, 34 of which had been adopted by the Council of Ministers as of January 1994.

Progress on issues addressed by the Social Charter has been mixed. Notable successes include the directive on harmonization of national regulations on collective redundancies (providing for information and consultation with workers' representatives in cases of mass layoffs), the directive covering the rights of workers in cases of mergers and firm insolvency, various directives on gender equality, and a series of directives on health and safety issues. On a number of other matters, however, the EU countries have failed to reach agreement. These include worker rights to informa-

\footnotetext{
${ }^{2}$ See Addison and Siebert (1991, 1994), Silvia (1991), and Turner (1993) for a detailed account of this debate.
}

tion, consultation, and participation; parental leave; equality between part-time and full-time workers; collective bargaining rights; and social protection benefits, including health care.

The various EU actors (governments, employers [UNICE], and unions [ETUC]) have different positions on these issues, and many of the arguments underlying the different positions reflect the competitive interests of the actors. We now briefly examine these various interests and positions, both to get a sense of how the different parties regard the role of labor policies in determining their competitiveness and to evaluate the extent to which these interests are overlapping-and therefore the extent to which standards are likely to be harmonized.

All the trade union bodies that make up the ETUC are in general agreement with the Social Charter (although some feel it does not go far enough). Streeck (1991) analyzed the uneasy alliance between northern European unions and southern European interests that led to support by the former for the Union's regional aid program, which will transfer funds for development to the less-developed countries, and support by the latter for the social initiatives that are aimed at equalizing labor standards across the EU. He notes, however, that "whether or not regional assistance and social policies can be properly balanced and finetuned, so that infrastructural investment in the South does not result in job loss in the North, and declining wage differentials under the Social Dimension do not enhance agglomeration [of industrial activities in the North] in spite of improvements in Southern infrastructure, remains an entirely open question" (Streeck 1991:328). Thus, we emphasize that although the unions are united behind the Social Charter, this unity is based on a potentially unstable balancing of competing interests.

Employers and governments are less united than are unions. Employers in highwage countries, notably Germany, Belgium, and the Netherlands, are broadly supportive of the Social Charter because it seeks to 
prevent capital flight from high-wage to low-wage countries; the governments of these countries fear an erosion of their tax bases as a result of enhanced capital mobility, and they do not want other countries to have the competitive advantage of fewer regulations. In particular, Germany and Denmark are supportive of matters relating to increased worker consultation, information sharing, and participation at the strategic level, as their industrial relations systems currently include such participative arrangements. Most of the other European countries have some lesser form of participation, ${ }^{3}$ and are in general support of consultation rights (Turner 1993). Britain and Ireland, the two countries without any significant form of worker participation, see the introduction of these measures as likely to render the Union, and their positions within it, less competitive (relative to the rest of the world).

Debates over other issues in the Charter reflect further differences in interests, which are likely to lead to variance in the mechanisms by which decisions are taken. One indication of such variance came at the summit in Maastricht in the Netherlands on December 10 and 11, 1991, when the countries decided that proposals regarding working conditions, information, and worker consultation will be decided by qualified majority voting (the larger countries have more votes than the smaller countries, and a qualified majority is defined as 56 out of 76 votes), whereas laws on rights of workers who are terminated, social protection, and third country nationals will have to be decided by unanimous vote. Issues concerning collective bargaining, strikes, and union recognition are likely to be resolved based on the principle of "subsidiarity" (that is, left entirely within the purview of individual countries). ${ }^{4}$ Moreover, Britain has been given the freedom to

\footnotetext{
${ }^{3}$ Ten out of the 12 countries have some form of works councils, for example.

${ }^{4}$ This situation could change, however, given current discussions among the 12 existing EU countries; and changes in rules may be made once the four new member countries enter in 1995 .
}

"opt out" of the Charter for the time being, with the option of "opting in" if it is willing to do so at a later date.

Thus, given that subsidiarity is the principle that is likely to be used for matters on which the parties do not reach agreement, and given that the idea of "opting out" might gain wider acceptance (for example, Danish voters ratified the Maastricht Treaty in May 1993 with the provision that Denmark could "opt out" of many specific parts of it), it is likely that there will be persistent differences in labor standards across the EU countries that could affect their competitive positions. Furthermore, mandating the equalization of certain high-cost benefits (for example, parental leave and employer-funded health care), even if it were politically possible, almost certainly would not equalize total compensation costs in the Union, given the wide variance in wages and other employer payments in the EU today. ${ }^{5}$

Compensation costs alone, however, do not determine international competitiveness. As Mosely (1990) and Lange (1992) have pointed out, high-wage countries are likely to have compensating advantages over low-wage countries, such as a more skilled work force, better infrastructure, and, perhaps, labor productivity that is high enough to offset the disadvantages of higher compensation costs. ${ }^{6}$ In this paper we ask, first,

\footnotetext{
${ }^{5}$ As noted in the introduction, in 1992 , total hourly compensation costs to employers in all of manufacturing ranged from a high of $\$ 25.94$ in Germany to a low of $\$ 5.01$ in Portugal, in U.S. dollars at current exchange rates. (U.S. Bureau of Labor Statistics, "International Comparisons of Hourly Compensation Costs for Workers in Manufacturing.")

${ }^{6}$ Lange (1992:253), for example, argues that despite differences in the social costs for producers across member states, the competitiveness of similar products produced in different countries in the Community of ten does not greatly vary. The reason seems to be that firms in these countries establish different mixes among infrastructure, skills, training, and technology that allow them to remain competitive. No clear cross-national disadvantages for the higher labor and social cost countries are evident.
} 
how close are manufacturing compensation costs and labor productivities across the twelve countries, and, second, what does that relationship imply for the likelihood of social dumping?

\section{Hourly Compensation, Productivity, and Unit Labor Costs}

\section{Data and Methods}

We obtained compensation cost data from an unpublished source used by the Bureau of Labor Statistics: "Hourly Compensation Costs for Production Workers in Manufacturing, 33 Countries."7 The BLS defines hourly compensation as

(1) all payments made directly to the workerpay for time worked (basic time and piece rates plus overtime premiums, shift differentials, other bonuses and premiums paid regularly each pay period, and cost-of-living adjustments), pay for time not worked (vacations, holidays and other leave), all bonuses and other special payments, and the cost of payments in kindbefore payroll deductions of any kind and (2) employer contributions to legally required insurance programs and contractual and private benefit plans. Hourly compensation costs do not include all items of labor costs: the costs of recruitment, employee training, and plant facilities and services-such as cafeterias and medical clinics-are not covered because data are not available for most countries. The labor costs not covered account for no more than $4 \%$ of total labor costs in any country for which the data are available. ${ }^{8}$

Since these data measure the cost to the employer of both wages and fringe benefits, they are clearly relevant to an investigation of the likelihood of social dumping. Moreover, the distinction between wages and fringes, on the one hand, and earnings per hour, on the other, does matter: Table 1 gives the percentage difference in 1977 and 1990 between hourly compensation in manufacturing, as defined by the BLS, and

\footnotetext{
${ }^{7}$ Sources for all of the data are cited in the appendix.

${ }^{8}$ U.S. Bureau of Labor Statistics, "International Comparisons of Hourly Compensation Costs for Workers in Manufacturing," Appendix.
}

earnings per hour in manufacturing as defined by the ILO- "cash payments received from employers, including remuneration for normal working hours; overtime pay; remuneration for time not worked; bonuses and gratuities; cost of living allowances; and special premiums." 9 In 1990, this difference between earnings and total cost to the employer ranged from $16.1 \%$ in Denmark to $84.4 \%$ in Belgium; note as well that between 1977 and 1990 it rose in every country except Italy and Spain.

Throughout our analysis, we present compensation results deflated both at market exchange rates and at purchasing power parity (PPP) exchange rates for GDP. Because we are attempting to assess employer incentives or, more precisely, capitalist incentives in a world of highly mobile capital, market exchange rates might seem at first blush to be the more appropriate measure. ${ }^{10}$ Because we want to take some account of the volatility of market exchange rates, we present the PPP results as well, but we prefer to interpret them in this context (that is, when used to deflate compensation costs) as representing estimates of longrange labor costs for extended investment projects, rather than purchasing power; presumably, a German employer does not care as much about the living standards of his or her Portuguese workers as about what his or her labor costs will be in a few years.

With respect to productivity, our primary goal is to address the policy question of whether an economic incentive for capital mobility within the EU exists; we do not propose any new methodologies for addressing the thorny and long-debated problem of how to measure productivity across countries. We follow the methodology of one of the most recent attempts to tackle this issue-Hooper and Larin (1989), who

${ }^{9}$ ILO, Yearbook of Labour Statistics.

${ }^{10} \mathrm{PPP}$ exchange rates would certainly be more appropriate for the analysis of workerincentives-that is, the question of differences in living standards obtainable from the wages paid across different countries. See Flanagan (1993) for an analysis of wage equalization and migration flows in the EU since the Treaty of Rome. 
calculate productivity and unit labor costs for ten countries, including six of the moredeveloped EU countries - and we refer the reader to that paper for a full accounting of the methods. ${ }^{11}$ Below, however, we describe the basic conceptual issue.

"Labor productivity," defined in this instance as GDP in manufacturing divided by total hours in manufacturing, must be converted to some kind of common currency to allow comparisons across countries. Market exchange rates, however, tend to introduce distortions. The United Nations has been working on this problem over the past few decades with its "International Comparison Project"; the result of this Project has been the calculation of Purchasing Power Parity (PPP) exchange rates, which come closer than market exchange rates to allowing a comparison of the "true value" of output across countries. PPP exchange rates are available through the late 1980s for total GDP, but this total GDP PPP may be an inappropriate measure when applied to manufacturing alone; it is better to weight individual output category PPPs used in manufacturing by their expenditure weights. ${ }^{12}$ Following Hooper and Larin, we use the expenditure weights in the following sectors to calculate our expenditure-weighted PPPs: Food, Beverages, and Tobacco; Clothing and Footwear; Fuel and Power; House Furnishings; Pharmaceutical-Therapeutical Health Care; Transport/ Communications; Recreation Equipment; and Consumer Durables. The measure thus derived is still far from perfect, but gets us closer to a "true" PPP for manufacturing alone. This approach has one major limitation, however: the expenditure weights are at present available only for $1980 .{ }^{13}$ Thus, to get a sense of the range of

\footnotetext{
${ }^{11}$ We also refer the reader to that paper's technical references. Two more recent technical contributions are Turvey (1990), which discusses the measurement of labor productivity, and Summers and Heston (1988), which discusses recent developments in the World Comparisons Project.

${ }^{12}$ Of course, output weights would be even better than expenditure weights, but they are not available.

${ }^{13}$ We emphasize that even this approach to measuring levels of labor productivity and unit labor costs
}

Table 1. Manufacturing Compensation Costs Compared to Earnings per Hour (Percentage Differential), 1977 and 1990, European Union Countries.

\begin{tabular}{lrr}
\hline Country & 1977 & $1990^{\circ}$ \\
\hline Belgium & 70.1 & 84.4 \\
Denmark & 6.9 & 16.1 \\
France & 64.0 & 82.7 \\
Germany & 63.8 & 71.6 \\
Greece & 56.3 & 60.8 \\
Ireland & 20.1 & 29.0 \\
Italy & 68.4 & 47.9 \\
Luxembourg & 39.3 & 39.9 \\
Netherlands & 66.4 & 79.7 \\
Portugal & 26.3 & 27.3 \\
Spain & 58.3 & 31.2 \\
United Kingdom & 15.5 & 20.0 \\
\hline
\end{tabular}

${ }^{\text {a}}$ For Italy, 1985; for Portugal, 1988.

For definitions of hourly compensation and earnings per hour, see text.

Source: U.S. BLS, "Hourly Compensation Costs for Production Workers in Manufacturing," and ILO Yearbook of Labor Statistics (earnings per hour in manufacturing).

possible estimates, we will do our productivity calculations using not only this conversion factor but also market exchange rates and unweighted GDP PPP exchange rates, both of which are available for later years.

Hooper and Larin's methodology is to calculate the unit labor cost (ULC) as the ratio between compensation costs converted at market exchange rates and output per hour in manufacturing converted at expenditure-weighted PPPs. The possibility we investigate in this paper is that producers from higher-cost countries "buy labor" by converting their own currency to local currency at market exchange rates and paying the local compensation costs, and then transport the product across borders in the tariff-free Europe of post-1992; thus, we want to translate compensation costs (numerator) at market exchange rates, but

is a crude one. It is important to keep in mind that we are measuring average rather than marginal labor productivity here; given the right data, we would take into account the size and quality of the capital stock as well. 
Table 2. Variance of Log Hourly Compensation and Maximum/Minimum Ratios by Industry in the European Union, 1977 and 1987.

\begin{tabular}{|c|c|c|c|c|c|c|c|}
\hline \multirow{3}{*}{$\begin{array}{l}\text { Industry } \\
\text { All Manufacturing }\end{array}$} & \multirow{3}{*}{$\begin{array}{l}\text { Year } \\
1977 \\
1987\end{array}$} & \multicolumn{2}{|c|}{ Variance of Logs } & \multicolumn{4}{|c|}{ Max/Min } \\
\hline & & \multirow{2}{*}{$\begin{array}{c}M \\
.316 \\
.319\end{array}$} & \multirow{2}{*}{$\begin{array}{l}P P P \\
.129 \\
.123\end{array}$} & \multirow{2}{*}{$\begin{array}{c}M \\
5.25 \\
6.71\end{array}$} & \multirow{2}{*}{$\begin{array}{l}P P P \\
2.73 \\
3.17\end{array}$} & \multicolumn{2}{|c|}{ Countries } \\
\hline & & & & & & $\begin{array}{l}\text { Belgium } \\
\text { Germany }\end{array}$ & $\begin{array}{l}\text { Portugal } \\
\text { Portugal }\end{array}$ \\
\hline $\begin{array}{l}\text { Food, Beverages, } \\
\text { Tobacco }\end{array}$ & $\begin{array}{l}1977 \\
1987\end{array}$ & $\begin{array}{l}.334 \\
.369\end{array}$ & $\begin{array}{l}.140 \\
.144\end{array}$ & $\begin{array}{l}5.48 \\
7.18\end{array}$ & $\begin{array}{l}2.96 \\
3.65\end{array}$ & $\begin{array}{l}\text { Denmark } \\
\text { Netherlands }\end{array}$ & $\begin{array}{l}\text { Portugal } \\
\text { Portugal }\end{array}$ \\
\hline Textile Mill Products & $\begin{array}{l}1977 \\
1987\end{array}$ & $\begin{array}{l}.310 \\
.323\end{array}$ & $\begin{array}{l}.123 \\
.116\end{array}$ & $\begin{array}{l}5.73 \\
6.54\end{array}$ & $\begin{array}{l}2.82 \\
3.32\end{array}$ & $\begin{array}{l}\text { Netherlands } \\
\text { Netherlands }\end{array}$ & $\begin{array}{l}\text { Portugal } \\
\text { Portugal }\end{array}$ \\
\hline Apparel & $\begin{array}{l}1977 \\
1987\end{array}$ & $\begin{array}{l}.334 \\
.335\end{array}$ & $\begin{array}{l}.142 \\
.128\end{array}$ & $\begin{array}{l}5.16 \\
6.22\end{array}$ & $\begin{array}{l}2.91 \\
2.98\end{array}$ & $\begin{array}{l}\text { Denmark } \\
\text { Denmark }\end{array}$ & $\begin{array}{l}\text { Portugal } \\
\text { Portugal }\end{array}$ \\
\hline $\begin{array}{l}\text { Lumber, Wood, } \\
\text { Furniture }\end{array}$ & $\begin{array}{l}1977 \\
1987\end{array}$ & $\begin{array}{l}.374 \\
.407\end{array}$ & $\begin{array}{l}.137 \\
.178\end{array}$ & $\begin{array}{l}6.75 \\
8.53\end{array}$ & $\begin{array}{l}3.27 \\
4.03\end{array}$ & $\begin{array}{l}\text { Belgium } \\
\text { Germany }\end{array}$ & $\begin{array}{l}\text { Portugal } \\
\text { Portugal }\end{array}$ \\
\hline Printing and Publishing & $\begin{array}{l}1977 \\
1987\end{array}$ & $\begin{array}{l}.323 \\
.410\end{array}$ & $\begin{array}{l}.128 \\
.168\end{array}$ & $\begin{array}{l}5.96 \\
7.46\end{array}$ & $\begin{array}{l}3.03 \\
3.57\end{array}$ & $\begin{array}{l}\text { Belgium } \\
\text { Denmark }\end{array}$ & $\begin{array}{l}\text { Portugal } \\
\text { Portugal }\end{array}$ \\
\hline Chemicals & $\begin{array}{l}1977 \\
1987\end{array}$ & $\begin{array}{l}.317 \\
.274\end{array}$ & $\begin{array}{l}.136 \\
.096\end{array}$ & $\begin{array}{l}5.19 \\
4.83\end{array}$ & $\begin{array}{l}3.09 \\
2.56\end{array}$ & $\begin{array}{l}\text { Belgium } \\
\text { Germany }\end{array}$ & $\begin{array}{l}\text { Portugal } \\
\text { Portugal }\end{array}$ \\
\hline Rubber and Plastics & $\begin{array}{l}1977 \\
1987\end{array}$ & $\begin{array}{l}.272 \\
.304\end{array}$ & $\begin{array}{l}.113 \\
.108\end{array}$ & $\begin{array}{l}4.44 \\
5.54\end{array}$ & $\begin{array}{l}3.03 \\
2.80\end{array}$ & $\begin{array}{l}\text { Belgium } \\
\text { Germany }\end{array}$ & $\begin{array}{l}\text { Portugal } \\
\text { Portugal }\end{array}$ \\
\hline Stone, Clay, and Glass & $\begin{array}{l}1977 \\
1987\end{array}$ & $\begin{array}{l}.290 \\
.317\end{array}$ & $\begin{array}{l}.104 \\
.109\end{array}$ & $\begin{array}{l}5.23 \\
5.97\end{array}$ & $\begin{array}{l}2.48 \\
3.16\end{array}$ & $\begin{array}{l}\text { Belgium } \\
\text { Belgium }\end{array}$ & $\begin{array}{l}\text { Portugal } \\
\text { Portugal }\end{array}$ \\
\hline $\begin{array}{l}\text { Primary Metal } \\
\text { Manufacturing }\end{array}$ & $\begin{array}{l}1977 \\
1987\end{array}$ & $\begin{array}{l}.250 \\
.238\end{array}$ & $\begin{array}{l}.085 \\
.085\end{array}$ & $\begin{array}{l}5.00 \\
5.41\end{array}$ & $\begin{array}{l}2.34 \\
2.79\end{array}$ & $\begin{array}{l}\text { Belgium } \\
\text { Germany }\end{array}$ & $\begin{array}{l}\text { Portugal } \\
\text { Portugal }\end{array}$ \\
\hline $\begin{array}{l}\text { Fabricated Metal } \\
\text { Products }\end{array}$ & $\begin{array}{l}1977 \\
1987\end{array}$ & $\begin{array}{l}.285 \\
.303\end{array}$ & $\begin{array}{l}.113 \\
.111\end{array}$ & $\begin{array}{l}4.95 \\
5.96\end{array}$ & $\begin{array}{l}2.62 \\
3.10\end{array}$ & $\begin{array}{l}\text { Belgium } \\
\text { Belgium }\end{array}$ & $\begin{array}{l}\text { Portugal } \\
\text { Portugal }\end{array}$ \\
\hline $\begin{array}{l}\text { Machinery, Except } \\
\text { Electrical }\end{array}$ & $\begin{array}{l}1977 \\
1987\end{array}$ & $\begin{array}{l}.311 \\
.303\end{array}$ & $\begin{array}{l}.136 \\
.113\end{array}$ & $\begin{array}{l}4.91 \\
5.86\end{array}$ & $\begin{array}{l}3.05 \\
2.77\end{array}$ & $\begin{array}{l}\text { Belgium } \\
\text { Germany }\end{array}$ & $\begin{array}{l}\text { Portugal } \\
\text { Portugal }\end{array}$ \\
\hline $\begin{array}{l}\text { Electric and Electronic } \\
\text { Equipment }\end{array}$ & $\begin{array}{l}1977 \\
1987\end{array}$ & $\begin{array}{l}.274 \\
.255\end{array}$ & $\begin{array}{l}.118 \\
.090\end{array}$ & $\begin{array}{l}4.26 \\
4.51\end{array}$ & $\begin{array}{l}2.74 \\
2.42\end{array}$ & $\begin{array}{l}\text { Belgium } \\
\text { Germany }\end{array}$ & $\begin{array}{l}\text { Portugal } \\
\text { Portugal }\end{array}$ \\
\hline $\begin{array}{l}\text { Transportation } \\
\text { Equipment }\end{array}$ & $\begin{array}{l}1977 \\
1987\end{array}$ & $\begin{array}{l}.214 \\
.254\end{array}$ & $\begin{array}{l}.075 \\
.084\end{array}$ & $\begin{array}{l}3.76 \\
5.84\end{array}$ & $\begin{array}{l}2.52 \\
2.76\end{array}$ & $\begin{array}{l}\text { Germany } \\
\text { Germany }\end{array}$ & $\begin{array}{l}\text { Portugal } \\
\text { Portugal }\end{array}$ \\
\hline
\end{tabular}

Notes: $\mathrm{M}=$ converted at market exchange rates; PPP = converted at unweighted GDP PPP exchange rates; Max/Min = ratio of compensation in highest-cost country to compensation in lowest-cost country. Maximum/ minimum countries listed are based on market exchange rates.

Source: U.S. BLS, "Hourly Compensation Costs for Production Workers in Manufacturing."

because we want to get some measure of the "innate value" of the product produced, we use weighted PPP exchange rates to convert the output measure (the denominator). ULC can then be interpreted as the labor cost per unit of output, or labor costs controlling for labor productivity. We also report ULCs where the numerator and denominator are converted by the same exchange rate, again to give some sense of the range of possible values.

\section{Results}

Table 2 presents two measures of the inequality of compensation costs in the $\mathrm{EU}$ in 1977 and 1987, for all of manufacturing and for thirteen specific manufacturing industries, using both market and unweighted GDP PPP exchange rates: the variance of $\log$ compensation costs across the twelve countries, and the ratio between the costs of highest- and lowest-cost countries. Note that both measures of inequality tend to be higher under market exchange rates than under PPP exchange rates; the maximum/minimum ratio for 1977 ranges from 3.76 in transportation equipment to 6.75 in lumber, wood, and furniture when market exchange rates are used as the conversion factor, and from 2.34 in primary metals to 3.27 in lumber, 
Table 3. Output per Hour in Manufacturing, 1980 and 1986.

\begin{tabular}{|c|c|c|c|c|c|}
\hline Country & $\begin{array}{c}\text { Output } \\
\text { per Hour } \\
\text { U.S. \$, Market } \\
\text { Exch. Rates } \\
1980\end{array}$ & $\begin{array}{l}\text { Output } \\
\text { per Hour } \\
\text { U.S. \$, PPP } \\
\text { Exch. Rates } \\
1980\end{array}$ & $\begin{array}{c}\text { Output } \\
\text { per Hour } \\
\text { U.S. \$, Expend. } \\
\text { Weight PPP } \\
1980\end{array}$ & $\begin{array}{c}\text { Output } \\
\text { per Hour } \\
\text { U.S. \$, Market } \\
\text { Exch. Rates } \\
1986\end{array}$ & $\begin{array}{c}\text { Output } \\
\text { per Hour } \\
\text { U.S. \$. PPP } \\
\text { Exch. Rates } \\
1986\end{array}$ \\
\hline Belgium & 22.97 & 16.52 & 15.94 & 24.65 & 26.72 \\
\hline Denmark & 16.67 & 11.01 & 9.96 & 17.82 & 15.15 \\
\hline France & 17.38 & 13.01 & 11.46 & 21.34 & 21.67 \\
\hline Germany & 16.67 & 12.20 & 11.00 & 19.55 & 19.11 \\
\hline Greece & 7.88 & 8.04 & 6.33 & 7.57 & 11.54 \\
\hline Ireland" & 8.35 & 7.22 & 6.07 & - & - \\
\hline Italy & 14.25 & 14.75 & 11.85 & 19.32 & 22.40 \\
\hline Luxembourg & 17.30 & 12.84 & 12.20 & 20.55 & 22.22 \\
\hline Netherlands & 17.07 & 12.32 & 12.19 & 21.30 & 21.55 \\
\hline Portugal & 4.78 & 7.58 & 5.05 & 5.82 & 11.53 \\
\hline Spain & 11.61 & 11.74 & 11.12 & 16.14 & 22.68 \\
\hline United Kingdom & 9.43 & 7.85 & 6.51 & 11.45 & 14.14 \\
\hline
\end{tabular}

The last available output data for Ireland were for 1979.

Sources: GDP in manufacturing and number of employees from OECD National Accounts, Main Aggregates (except for Spain, for which GDP is from the World Bank World Tables); hours per week in manufacturing from ILO Yearbook of Labour Statistics; vacation and holiday weeks per year from European Trade Union Institute.

wood, and furniture when PPP exchange rates are used. Some other industries with large compensation cost gaps are printing and publishing, textile mill products, food, and stone, clay, and glass; among those with the lowest gaps are the heavier industries of electronic equipment, rubber and plastics, non-electrical machinery, and fabricated metal products. Note as well that, at market exchange rates, the maximum/ minimum ratio is higher in 1987 than in 1977 in all but one industry (chemicals), and the variance is higher in all but four industries, whereas at PPP exchange rates, the maximum/minimum ratio is lower in 1987 in four of the industries and the variance is lower in seven of the industries. ${ }^{14}$ Nevertheless, this table suggests three conclusions, to which we will return: there were large differences in compensation

\footnotetext{
${ }^{14}$ Flanagan (1993) found that Germany and Portugal had similar wage gaps at market exchange rates for all of manufacturing in 1988; surprisingly (considering the presumably higher cost of living masked by market exchange rates in Germany), he found a larger gap for PPP exchange rates than for market exchange rates. He did not provide these comparisons for the disaggregated manufacturing industries reported here.
}

costs across these countries, the size of these gaps varied by industry, and there was no significant narrowing of these gaps over the 1980s.

Of course, hourly compensation alone is not the entire story; ideally, our analysis would control for productivity as well. If the lower hourly compensation costs in the less-developed countries are matched by proportionally lower productivity levels, there is no economic incentive for social dumping. To address this issue, we calculate rough measures of unit labor costs (ULCs).

Table 3 presents labor productivity estimates in manufacturing for 1980 and 1986 using the three types of conversion factors discussed above (market exchange rates, unweighted GDP PPPs, and expenditureweighted PPPs). The table shows that the EU countries do indeed differ in labor productivity. ${ }^{15}$ Furthermore, within the same country, different values result from the use of different conversion factors; par-

\footnotetext{
${ }^{15}$ The estimate for Spain appears to be unreasonably large; note that Spain is the one country for which we needed to use a separate data source from the National Accounts (see the notes to Table 3).
} 


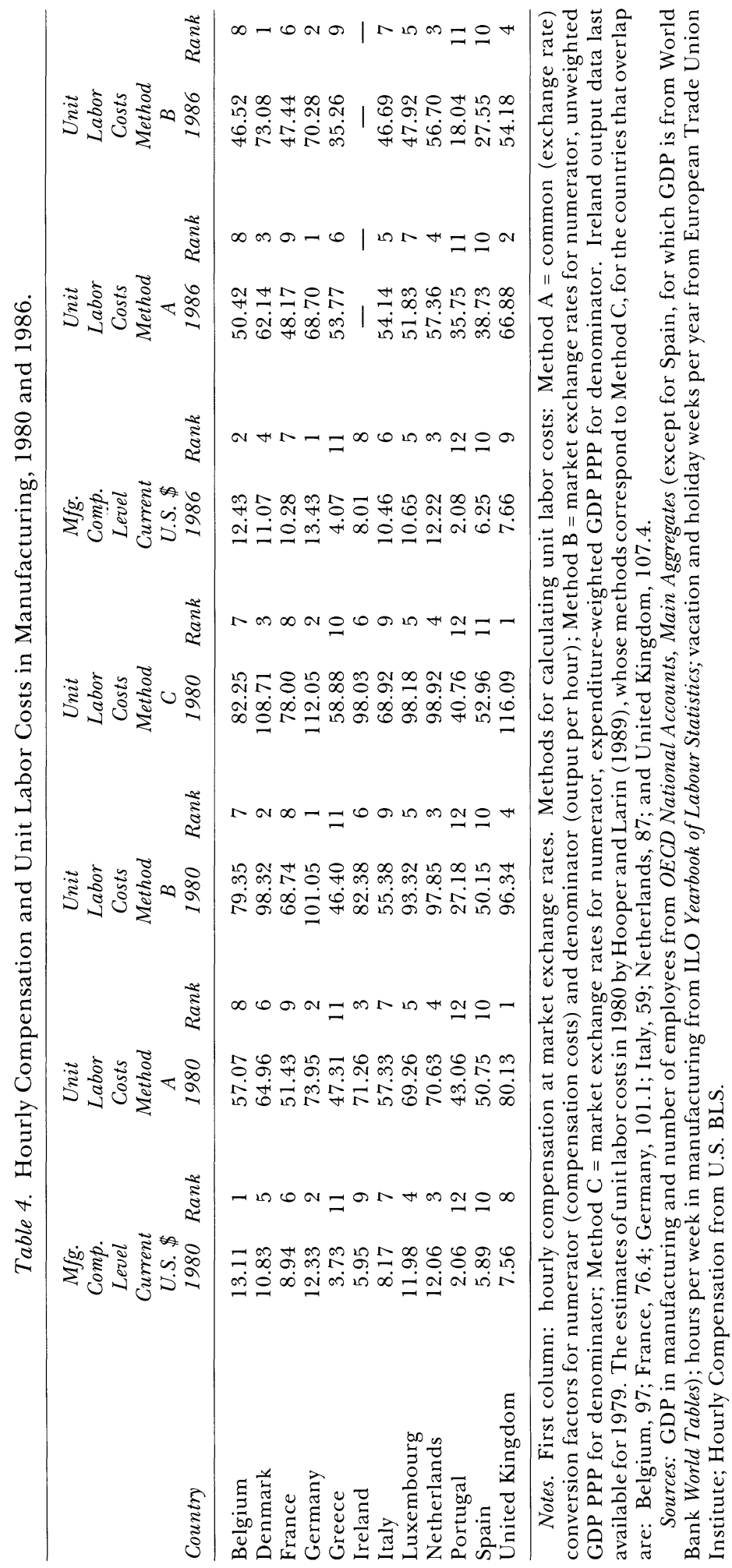


ticularly striking are differences between the results based on market exchange rates and PPPs. The productivity gaps between the less-developed and more-developed countries are greater when converted at market exchange rates. The expenditure weighting also seems to make a difference, particularly in Portugal, Italy, Greece, and Ireland, perhaps reflecting different balances of manufacturing in total GDP. Note that productivity grew in all of these countries between 1980 and 1986, but not at the same rate; we will discuss productivity growth rates below.

The first column of Table 4 reports average manufacturing hourly compensation levels in dollars (at market exchange rates) in the twelve countries and the ranking of those countries in terms of this measure in 1980 and 1986 . In 1980 , the five countries with the least expensive compensation costs, in ascending order of cost, were Portugal, Greece, Spain, Ireland, and the United Kingdom; Germany, the BeNeLux countries, and Denmark had the highest compensation costs.

The remaining columns of Table 4 present our three measures of manufacturing ULCs. The first (Method A) can be thought of as converting both the numerator and denominator at the same conversion factor (market exchange rates or PPPs); the second (Method B) converts the numerator at market exchange rates and the denominator at unweighted GDP PPPs; and the third (Method $\mathrm{C}$ ) converts the numerator at market exchange rates and the denominator at expenditure-weighted PPPs. ${ }^{16}$

Note that the ranking of the countries in terms of hourly compensation does not precisely coincide with the ranking in terms

\footnotetext{
${ }^{16}$ Hooper and Larin (1989) used GDP data from the U.S. BLS, which is not available for the six EU countries they do not analyze; for all the countries but Spain, we use National Accounts estimates, which differ somewhat from the BLS estimates. This difference in sources most likely explains the deviations from the Hooper and Larin ULC estimates reported in the note to the table. Note, however, that deviations of our ULC estimates from the Hooper and Larin estimates are all within $18 \%$. Recall that the expenditure weights are only available for 1980 .
}

of unit labor costs. For example, Belgium had the highest hourly compensation in 1980 but only the seventh-highest ULC due to high labor productivity, whereas the United Kingdom had the eighth-highest hourly compensation but the highest ULC (using expenditure-weighted PPP exchange rates in the denominator-Method $\mathrm{C}$ ) due to low labor productivity, as measured here. It is clear, then, that average labor productivity is not directly proportional to compensation.

In terms of the comparative magnitudes of the ULCs, the main finding is that labor productivity in manufacturing was between 3.5 times (at market exchange rates) and 1.6 times (at GDP PPPs) as large in Germany as in Portugal in 1980, while hourly compensation costs were between 6 and 3 times larger, yielding unit labor costs between 1.7 and 3.7 times larger in Germany than in Portugal. The Greek and Spanish ULCs were also low (about one-half of the German ULC, at expenditure-weighted PPPs).

We cannot be confident about the precise magnitudes of these unit labor cost measures, but lacking a systematic bias leading to gross overestimation of labor productivity in Portugal, Greece, and Spain compared to Germany, it does look as though unit labor costs were lower in those countries than in Germany. In fact, if anything, we might expect the bias to go in the opposite direction: marginal labor productivity (or perhaps even "potential productivity") should be underestimated by average productivity in less-developed countries compared to more-developed countries, given the larger and more advanced capital stocks in the more-developed countries.

In sum, our analysis of levels of manufacturing unit labor costs in 1980 indicates that the dramatic compensation differentials across the countries are not entirely offset by labor productivity differentials. The last two columns of Table 4 measures unit labor costs in 1986 (the last year for which all the data are available): note that while ULCs dropped everywhere over the period 1980-86 (indicating faster growth 
Table 5. Growth Rate of Real Manufacturing Hourly Compensation in the European Union, 1980-1989.

\begin{tabular}{lcc}
\hline & $\begin{array}{c}\text { Annualized } \\
\text { Real Comp. } \\
\text { Growth, '80-'89 } \\
\text { Own Country } \\
\text { Currency E' } \\
\text { Prices }\end{array}$ & $\begin{array}{c}\text { Annualized } \\
\text { Real Comp. } \\
\text { Growth, '80-'89 } \\
\text { Real DM } \\
\text { Current } \\
\text { Exch. Rates }\end{array}$ \\
\hline Belgintry & .57 & -.66 \\
Denmark & .50 & 1.34 \\
France & 2.03 & 1.56 \\
Germany & 1.65 & 1.65 \\
Greece & 2.88 & 2.13 \\
Ireland & 1.94 & 3.30 \\
Italy & .75 & 3.79 \\
Luxembourg & .07 & -1.27 \\
Netherlands & 1.30 & .36 \\
Portugal & -.61 & 1.11 \\
Spain & 1.33 & 2.72 \\
United Kingdom & 1.68 & 1.50 \\
\hline
\end{tabular}

"Figures for Luxembourg are for 1988.

Sources: Hourly Compensation from U.S. BLS; price indexes and exchange rates from $O E C D \mathrm{Na}$ tional Accounts, Main Aggregates Vol.1, 1960-1989.

in productivity than in compensation), they fell slightly more in percentage terms in the less-developed countries (Portugal and Spain in particular) than in some of the more-developed countries (Germany and Denmark): for example, the ULC gap between Germany and Portugal rose to between 1.9 times and 3.9 times (converting the denominator at market and unweighted GDP PPP exchange rates, respectively). We next examine this apparent lack of convergence in more detail.

\section{Trends in Manufacturing Compensation Costs}

Our goal in this section and the next is to examine movements of hourly compensation and productivity in the EU countries over the 1980s to get a sense of whether the components of ULC have been converging.

First, we examine whether hourly compensation costs in manufacturing across the twelve countries are converging. The answer to that question not only will tell us about movements in the numerator of the ULC formula, but is also interesting in itself. ${ }^{17}$ Table 5 shows annual growth rates of real manufacturing compensation costs over the 1980s in the twelve countries at own-country prices (column one) and at common currency and prices in German Deutschmarks (column two). Note that exchange rate movements introduce distortions; from the perspective of the German investor, the growth rate of compensation costs at German prices and market exchange rates is relevant to the question of whether he or she should invest, whereas from the perspective of the Portuguese worker, the growth rate in his or her own currency at Portuguese prices is relevant to that worker's personal well-being. For the social dumping question, we must focus on the perspective of an outside investor; we choose Germany for obvious reasons.

The table does not indicate a high degree of convergence, particularly when Germany, Denmark, and the United King-

\footnotetext{
${ }^{17}$ Leamer (1993:67) used a different data set to examine convergence of industrial wages in the EU, among other groups of countries. He concluded that "a considerable amount of wage equalization occurred between 1978 and 1989 [within the EU]." In contrast in his analysis of wage dispersion among the original EC6 and the EC9, Flanagan (1993:174), who examined some of the same data we do, found that

the dispersion of labor costs and wages eventually falls dramatically in the late 1970 s, only to rise again in the last half of the 1980s. By the end of the period (1989), the dispersion of hourly labor costs in manufacturing among the original EC6 is only slightly below dispersion in 1960. The same is true of the data for the EC9... Much the same may be said of the Swedish Employers' Confederation measures of hourly wages in manufacturing and construction.
}

Van Mourik [1989:101] found that

using a very straight-forward neoclassical model of international trade, from which the assumption of identical production functions among countries has been dropped, we were able to show that wage differentials [within the EU] may be the result of different factor proportions as well as different elasticities of substitution and different overall rates and biases of technological progress. The parameter estimates have revealed that the empirical values of the elasticity of substitution favor wage convergence, but that the movement is counteracted by the various values of labor's share in national income. 
dom are compared to Portugal, Greece, and Spain. Recall as well that neither the variance of log wages nor the maximum/ minimum ratio for all of manufacturing dropped between 1977 and 1987 (except for a slight drop of the variance at PPP exchange rates; see Table 2$).{ }^{18}$

\section{Trends in Productivity and Unit Labor Costs}

Now consider Table 6 , which shows the growth rate of manufacturing productivity (both in output per employee and in output per hour) over the 1980s in eleven of the twelve countries.

The first column of Table 6 indicates that productivity growth (measured in terms of real output per employee) from 1980 to 1987 was three times higher in Portugal and Spain than in Germany, and also somewhat higher in Greece than in Germany. ${ }^{19}$ In conjunction with the compensation growth rates reported in Table 5 and the ULC results for 1986 reported in Table 4, this result seems to indicate that from the perspective of a German investor, unit labor costs are not significantly converging. Note, in particular, that the growth rate of hourly compensation in German currency over the period 1980-89 was actually less for Portugal than for Germany or Denmark, and higher overall, but not higher than the output-per-employee growth rate differential, in Spain than in Germany or Denmark (see Table 5). Only in the BeNeLux countries (because of low compensation cost growth in those countries) and the United Kingdom (because of high productivity growth) do ULCs appear to have been converging with ULCs in lessdeveloped countries. In sum, it does not look as though the more-developed and less-developed countries (or, at least, Ger-

\footnotetext{
${ }^{18}$ Flanagan (1993) found somewhat more convergence among the EC-6 and EC-9 countries, but also found an increase in dispersion in the late 1980s.

${ }^{19}$ The results for the growth rate of output per hour are more mixed. Note, however, the differences in periods imposed by data limitations, explained in the note to Table 6.
}

Table 6. Growth Rate of Manufacturing Productivity in the European Union in the $1980 \mathrm{~s}$.

\begin{tabular}{lcc}
\hline & $\begin{array}{c}\text { Annualized } \\
\text { Growth of } \\
\text { Real Output } \\
\text { per Employee } \\
1980-1987\end{array}$ & $\begin{array}{c}\text { Annualized } \\
\text { Growth of } \\
\text { Real Output } \\
\text { per Hour } \\
1980-1989^{\mathrm{a}}\end{array}$ \\
\hline Belgium & 4.01 & 6.17 \\
Denmark & .22 & .40 \\
France & 2.57 & 3.83 \\
Germany & 1.07 & 1.94 \\
Greece & 1.21 & -.30 \\
Ireland & - & - \\
Italy & 4.96 & 5.41 \\
Luxembourg & 2.96 & 5.48 \\
Netherlands & 4.60 & 4.36 \\
Portugal & 4.09 & 1.68 \\
Spain & 3.36 & 3.17 \\
United Kingdom & 5.54 & 6.37 \\
\hline
\end{tabular}

'Years for growth rate of output/hour: Belgium, '80-'88; Greece, '81-'88; Luxembourg, '80-' 88 ; Netherlands, '80-'87; Portugal, '80-'86; Spain, '86-' 89 ; United Kingdom, '80-'86.

Sources: Output/Employee index from World Bank World Tables; GDP, price indexes, and employees from OECD National Accounts, Main Aggregates (except Greece Employment, which is from ILO Yearbook of Labour Statistics); hours per week in manufacturing from ILO Yearbook of Labour Statistics; vacation and holiday weeks per year from European Trade Union Institute.

many and Denmark compared to Spain and Portugal) were significantly converging in ULCs as the year 1992 approached.

Even if our measures of productivity growth are inexact (given our data limitations on output per hour and the inherent problems with attempting to measure productivity), keep in mind that the numbers on hourly compensation growth rate are probably more reliable, and that we may be able to draw inferences about the growth of ULCs from those numbers alone. That is, if productivity convergence is occurring in the classical sense (less-developed countries catching up with more-developed countries),${ }^{20}$ then the fact that hourly compen-

\footnotetext{
${ }^{20}$ For a recent test of this convergence hypothesis, which finds convergence among the world's most industrialized countries as well as among countries with above-average literacy rates, see Zagardo (1991).
} 
sation is not growing much faster in the less-developed countries (particularly Portugal and Greece) than in the more-developed countries indicates that ULCs may be growing farther apart.

This analysis of the compensation and productivity structures of the EU countries suggests two basic conclusions. First, productivity differences do not appear to account for all of the big compensation differentials between the more-developed and less-developed EU countries; the economic incentive for moving production to lowercost countries does seem to be present at this aggregate level of analysis. Second, in terms of relative magnitudes of unit labor costs, the countries were not significantly converging as they approached the single market.

\section{Evidence on Foreign Direct Investment in the EU}

The question at hand is whether, with the removal of most barriers to trade and capital mobility within the EU, producers in high-cost countries will move their operations to low-cost regions. Until an EU directive of July 1, 1990, regulation of inward foreign direct investment (FDI) was primarily controlled by individual member governments. ${ }^{21}$ The directive essentially abolished all barriers to the free movement of capital within EU member states, although some capital controls will remain in place in Greece and Portugal until 1995. In addition, the Council Regulation on the Control of Concentrations Between Undertakings adopted in 1989 regulates mergers, takeovers, and acquisitions within or outside the EU. The United Nations (1993:11) reported that the most significant changes within the Union affecting inward investment during the late 1980s took place in France, Spain, Portugal, Denmark, Greece, and Ireland.

\footnotetext{
${ }^{21}$ Inward FDI refers to FDI entering a country; outward FDI refers to FDI exiting a country. We adopt this terminology from the United Nations (1993).
}

Moreover, unlike the situation in North America, where many argued that U.S. capital was free to locate in Mexico with or without NAFTA, much of the single market legislation in the EU has involved removing substantial indirect barriers to the movement of capital. Three primary types of impediments to the production and movement of goods have discouraged the free movement of capital: physical barriers (for example, costs of customs duties, tariffs, and delays on the re-importing of final products), technical barriers (for example, different standards for individual products adopted in different states for health, safety, environmental, or consumer protection, and rules regarding public procurement), and fiscal barriers (for example, VAT taxes, differential excise duties, and other indirect taxes). ${ }^{22}$ These are the types of barriers that the internal market program was designed to eliminate.

Although these controls were still being dismantled during the 1980s, intra-EU FDI increased from one-quarter of the total inward stock in the EU in 1980 to $40 \%$ in 1990 , when it reached a level of approximately $\$ 280$ billion (United Nations 1993:31). At least three caveats must be borne in mind, however, in considering these figures: (1) investment before December 31, 1992, reflected whatever was happening because of (or in spite of) barriers that were removed for intra-EU transactions after 1992; (2) the terms of the Social Charter, and therefore the cost of investing in the less-developed countries after 1992, have been subject to considerable uncertainty for potential investors and others; and (3) non-European countries may have invested heavily in certain EU countries during the 1980s in order to gain a foothold before the end of 1992. We now present an exploratory analysis of FDI flows to EU countries during the 1980 s to get a sense of the responsiveness of FDI to labor costs prior to the single market, keeping in mind these caveats. Due to data limita-

\footnotetext{
${ }^{22}$ See Cecchini (1988) and Commission of the European Communities (1988) for further analysis of these issues.
} 
tions, we will confine our analysis to aggregate FDI activity in each of the countries during the period 1980-88.

It is notoriously difficult to find reliable measures of $\mathrm{FDI} ;{ }^{23}$ we report here some data from a recent U.N. attempt to fill this gap. Table 7 shows the stock of inward FDI for the EU countries in 1979 (column one), as well as the aggregate flow of inward FDI and the balance of FDI flows (inward flow minus outward flow, or net flow) over the period 1980-88 (columns 2 and 3), all in 1982 U.S. dollars. Note that the inflow of foreign direct investment during the $1980 \mathrm{~s}$ was larger than the total stock of inward foreign direct investment in 1979 in all of the countries except Denmark, Germany, Ireland, the Netherlands, and the United Kingdom, indicating that the flow of FDI into the less-developed EU countries in particular during the 1980s was large compared to past experience (see the first two columns). ${ }^{24}$

${ }^{23}$ The United Nations (1993:v) notes that "despite the increasing importance of foreign direct investment in the world economy, published sources or readily accessible databases that provide homogeneous and accurate data on the investments and other activities of transnational corporations are scarce." Molle (1990) attempted to analyze flows of FDI in the EU from sources of FDI that were available at the time of his writing, with the caveat that "because, on the whole, inward investment is documented better than outward investment, the former has been taken as the main basis of our calculations.... Consequently, although [his analysis] gives the best possible picture of DI in Europe, the figures...can only be regarded as indications, or as the likely order of magnitudes" (p. 245n). He concludes that his figures "indicate that there is a net flow of capital towards the less developed EU countries; in other words, they confirm that jobs are indeed going to the people, although formerly people used to go to where the jobs were" (p. 235).

${ }^{24}$ In addition, within the EU, both national and cross-border mergers and acquisitions made by Europe's leading 100 firms (which might be thought of as camouflaged foreign direct investment) have been increasing dramatically, from 303 mergers and acquisitions in 1987 to 622 in 1990. The locus of cross-border acquisitions is primarily engineering, chemicals, electronics, pharmaceuticals, transport, and banking. The number of new companies from outside the EU establishing a foothold in the EU via mergers or acquisitions increased from about 30 in 1987 to about 125 in 1990. (Data from the Economist, December 7-13, 1991, and July 4-10, 1992.)
Table 7. Foreign Direct Investment Stocks and Flows in the European Union.
(Millions of 1982 U.S. Dollars).

\begin{tabular}{lrrr}
\hline & Inward & Inward & \\
& FDI & FDI & FDI \\
& Stock, & Flow, & Balance \\
Country & 1979 & $1980-88$ & $1980-88$ \\
\hline Belgium/Lux. & 9742 & 13610 & 6079 \\
Denmark & 5413 & 1284 & -1460 \\
France & 16713 & 25939 & -14043 \\
Germany & 48771 & 8026 & -40319 \\
Greece & 4355 & 7786 & 7528 \\
Ireland & 2449 & 1329 & 157 \\
Italy & 11181 & 14873 & -2879 \\
Netherlands & 22926 & 19745 & -22647 \\
Portugal & 631 & 1895 & 1671 \\
Spain & 6103 & 23036 & 19200 \\
United Kingdom & 59052 & 49790 & -67789
\end{tabular}

Notes: Belgium and Luxembourg are combined in these data. Ireland FDI stock data are from 1981. "Inward FDI Stock" means existing stock of FDI from other countries; "Inward FDI Flows" means flows of FDI from other countries; "FDI Balance" means flows of FDI from other countries (inward FDI flows) minus flows of FDI to other countries (outward FDI flows).

Source: United Nations, World Investment Directory 1992: Developed Countries, Country Tables 2, 6.

Although these numbers are the result of an attempt by the United Nations to centralize data-gathering efforts so that foreign direct investment could be measured systematically, there are nevertheless some serious questions about the comparability of these data across countries. ${ }^{25}$ Still,

\footnotetext{
${ }^{25}$ As the United Nations (1993:68; the source of these data) notes:

There is a notorious lack of comparability of the FDI data of different countries. There are three main causes for the lack of comparability and discrepancies. First, countries differ in their definitions of FDI, since most depart in one way or another from the conventions recommended by IMF or OECD [ that is, some countries include all three components of FDI (equity capital, reinvested earnings, and intercompany loans) and some do not]. Second, countries differ in their methods of data collection; a principal problem is the difficulty of identifying the ultimate beneficiary as opposed to the immediate beneficiary of FDI. [Other problems are the exclusive use of foreign exchange records or regulatory institutions, as opposed to company surveys, in some countries, as well as differences in industrial coverage and the treatment of banks and other financial institutions.]
} 


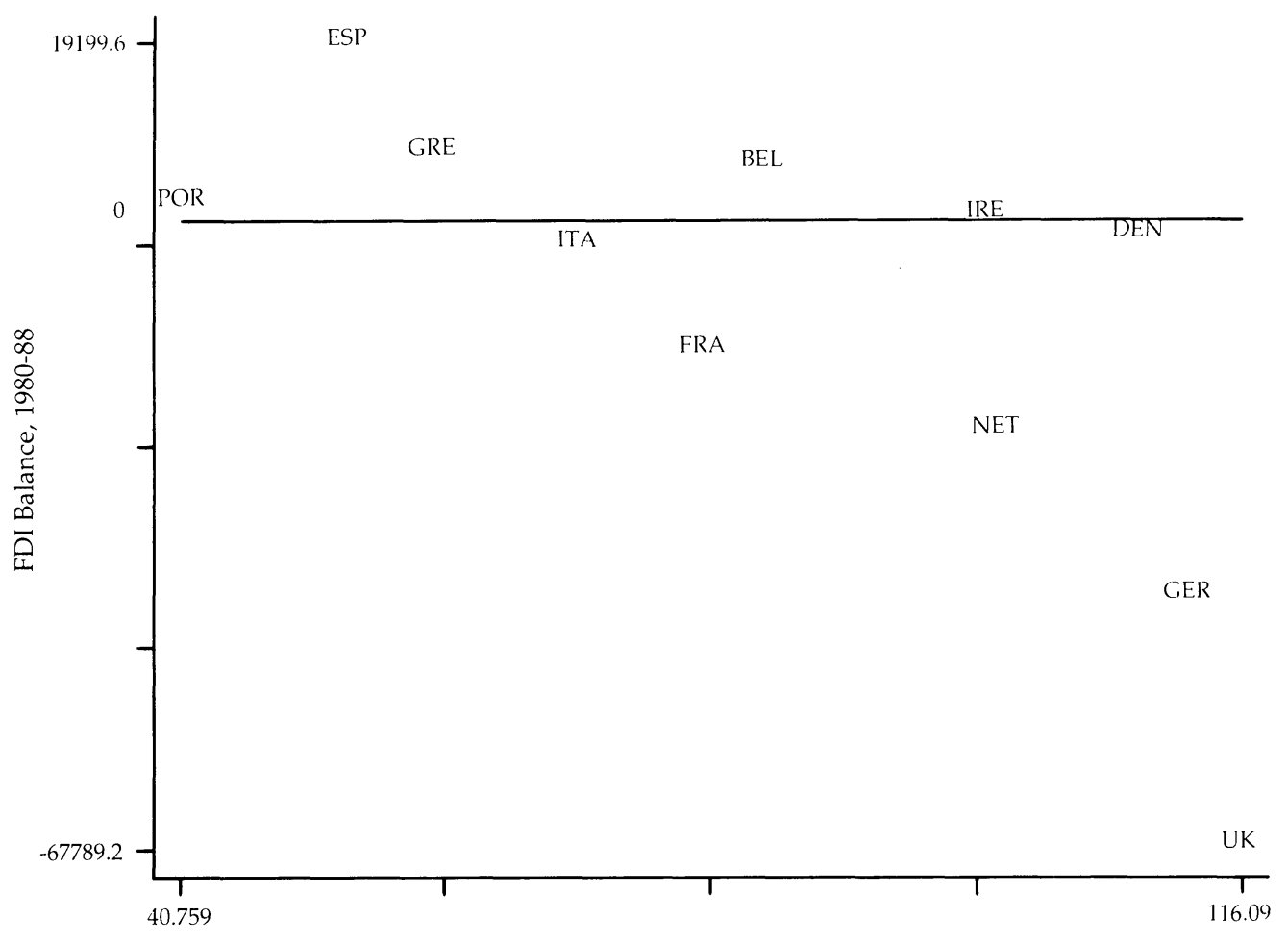

1980 Unit Labor Cost, method C

Figure 1. Relationship Between 1980 Unit Labor Cost and 1980-88 FDI Balance, 11 EU Countries.

bearing that in mind, we can examine the basic relationship between the FDI inflows and balances over the course of the 1980s presented in Table 7 and the measures of 1980 compensation and ULCs presented in Table 4. Whereas the correlations of the 1980-88 inward FDI flows with all the measures of 1980 compensation and unit labor costs are positive and below 0.5 , the correlation of 1980-88 balances of FDI flows with the measures of labor costs in 1980 are as follows: compensation, -0.29 ; unit labor cost method A, -0.84 ; unit labor cost method

Third, corporate accounting practices and valuation methods differ between coun tries [that is, in the use of historical valuation of assets (which disregards the effects of inflation, for example), methods of consolidation, and the treatment of capital gains and losses].
B, -0.64; and unit labor cost method C, $-0.75 .{ }^{26}$ These correlations suggest that the lower labor cost countries received the largest net flows of FDI during the 1980s; this relationship between $1980-88$ balance of FDI flows and 1980 unit labor cost (method C) is graphed in Figure 1.

\footnotetext{
${ }^{26}$ Although the correlation of FDI balance with compensation is not statistically significant at conventional levels, the negative correlations of all three measures of unit labor costs with FDI balance are significant at the 0.01 level. One unit labor cost measure is positively and significantly correlated with FDI inflows at the 0.10 level; the other measures of compensation and unit labor cost are not statistically significantly correlated with FDI inflows. The rankorder correlations (a more non-parametric measure) of compensation and ULCs with FDI balance are $-0.45,-0.84,-0.70$, and -0.78 , respectively.
} 
Moreover, although two countries with relatively high labor costs-Belgium/Luxembourg and Ireland-had a puzzling positive FDI flow balance over the years 198088 , the only other countries with positive balances of FDI flows over those years were the countries with the three lowest unit labor costs: Spain, Greece, and Portugal. These findings indicate that although some of the more-developed, higher-cost countries received large inflows of FDI, they also had large outflows, so that the balances of FDI flows to the EU countries in the 1980s nevertheless bore a strong negative relationship with labor costs, particularly unit labor costs. ${ }^{27}$

There are several different types of approaches to modeling the determinants of FDI inflows: those based on perfect markets suggest that differential rates of return and risk should be important determinants of FDI; those based on market imperfections suggest that differential firm advantages (such as financing or marketing skills) are important; those based on propensity to invest suggest that factors such as existing investment and exchange rates should be important; and FDI inflow theories suggest that factors related to the host country, such as tax rates, political stability, and labor costs, should be important (Agarwal 1980). We include three key variables from the literature in our analysis: domestic demand (as measured by GDP), labor factors (measured here as labor costs), and existing FDI stock. ${ }^{28}$ We do not propose to develop a general theory of the determinants of FDI here; rather, we want to get a

\footnotetext{
${ }^{27}$ The United Kingdom, for example, while having the largest FDI inflow, also had the largest net FDI outflow.

${ }^{28}$ See, for example, Cushman (1987). We include 1979 inward FDI stock because existing stock likely bears a positive relationship to subsequent flows for reasons such as reinvestment of earnings and contagion effects. We include GDP to control for the size of the domestic market. We lack reliable data over the course of the decade for all these countries on return on FDI, tax rates, political stability, and so on; studies using these variables are generally based on more limited samples of the developed countries. Froot and Stein (1991) found that exchange rates
}

basic sense of whether FDI movements were responsive to labor cost differentials across the European Union countries over the 1980s. ${ }^{29}$

Table 8 reports the results of a regression in which the dependent variable is the logarithm of 1980-88 aggregate real inward FDI flow for each country (from Table 7 ) and the independent variables are the logarithms of the various measures of compensation costs and ULCs in 1980 (from Table 4), stock of inward FDI in 1979, and aggregate GDP over the period 1980-88. The results indicate that, after controlling for existing inward FDI stock and GDP, FDI inflows during the 1980s bore a strong negative relationship to the various measures of ULCs in the 1980: in regressions (4), (6), and (8), a one-percent difference in the various measures of ULC is associated with a $-2.62 \%$ to $-4.24 \%$ difference in FDI inflow, and the coefficients on the measures of ULC are statistically significant at the $10 \%$ level or better. ${ }^{30}$

We emphasize that our analysis of foreign direct investment is not complete. For example, a thorough analysis of flows of foreign direct investment over the 1980s would require data that are more complete and consistent across countries, as well as a model explaining the initial levels and why the shares are shifting. One finding that may be taken as suggestive, however, is that the balance of foreign direct investment flows was largest in some of the less-developed countries, which is consistent with fears regarding social dumping. On the other hand, although we find a strong negative relationship between 1980 ULCs and

influenced FDI inflows in to the United States, but not the inflows into many other countries; although we do not include exchange rates separately, we recognize that the sizes of the labor cost differentials in our study are also a function of exchange rate differentials.

${ }^{29}$ Further, we certainly are not claiming that there cannot be any excluded variables that are correlated with labor costs that might be true causal factors on FDI.

${ }^{30}$ Regression results based on 1986 compensation and labor cost data are qualitatively similar to the results reported here based on 1980 labor cost data. 
Table 8. Determinants of Aggregate 1980-88 Real Inward FDI Flows, European Union Countries. (Standard Errors in Parentheses)

\begin{tabular}{|c|c|c|c|c|c|c|c|c|}
\hline Independent Variable & (1) & (2) & (3) & (4) & (5) & (6) & (7) & (8) \\
\hline $\begin{array}{l}1980 \\
\text { Compensation }\end{array}$ & $\begin{array}{c}0.74 \\
(0.70)\end{array}$ & $\begin{array}{l}-0.89 \\
(0.76)\end{array}$ & & & & & & \\
\hline $\begin{array}{l}1980 \text { ULC. } \\
\text { Method A }\end{array}$ & & & $\begin{array}{c}0.73 \\
(2.05)\end{array}$ & $\begin{array}{r}-4.24^{*} \\
(1.93)\end{array}$ & & & & \\
\hline $\begin{array}{l}1980 \text { ULC: } \\
\text { Method B }\end{array}$ & & & & & $\begin{array}{c}0.53 \\
(0.99)\end{array}$ & $\begin{array}{l}-2.62^{*+} \\
(1.00)\end{array}$ & & \\
\hline $\begin{array}{l}1980 \text { ULC, } \\
\text { Method C }\end{array}$ & & & & & & & $\begin{array}{c}0.34 \\
(1.22)\end{array}$ & $\begin{array}{l}-3.51^{* * *} \\
(0.92)\end{array}$ \\
\hline $\begin{array}{l}1979 \text { Inward } \\
\text { FDI Stock }\end{array}$ & & $\begin{array}{c}0.64 \\
(0.51)\end{array}$ & & $\begin{array}{r}1.17^{*} \\
(0.53)\end{array}$ & & $\begin{array}{c}1.46^{* *} \\
(0.55)\end{array}$ & & $\begin{array}{l}1.57^{* * *} \\
(0.42)\end{array}$ \\
\hline $\begin{array}{l}1980-88 \\
\text { Real GDP }\end{array}$ & & $\begin{array}{c}0.39 \\
(0.41)\end{array}$ & & $\begin{array}{l}-0.06 \\
(0.42)\end{array}$ & & $\begin{array}{c}-0.19 \\
(0.40)\end{array}$ & & $\begin{array}{l}-0.28 \\
(0.32)\end{array}$ \\
\hline R-squared & 0.11 & 0.65 & 0.01 & 0.75 & 0.03 & 0.79 & 0.01 & 0.87 \\
\hline
\end{tabular}

Notes: Belgium and Luxembourg are combined in these data. Ireland FDI stock data are from 1981. All variables are in logarithms. Regressions include a constant (not reported).

*Statistically significant at the $10 \%$ level; ${ }^{* *}$ the $5 \%$ level; $* * *$ the $1 \%$ level.

inward FDI flows during the 1980s (after controlling for the existing stock of inward FDI and GDP), the gross inward investment flows to the lower-cost countries were not as large as the gross inflows to many of the higher-cost countries.

One major question that this analysis raises, then, is why we have not yet seen massive foreign investment in the less-developed countries, given the differences in labor costs. Several plausible explanations can be offered. The first is that the direct and indirect controls on the movement of capital that have only recently been removed were significantly discouraging investment. Second, it may be that the level of uncertainty regarding the final terms of the Social Charter has been high enough to induce investors to wait until the issues are settled. A third possibility was suggested by Streeck (1991), who discussed the transformation of the German economy toward a high-wage, high-skill, and high-value-added production system, with the abandonment by employers of the low-wage, low-skill model. ${ }^{31}$ Employers in high-wage countries

\footnotetext{
${ }^{31}$ This consideration is clearly related to the "flexible specialization" debate; see Piore and Sabel (1984).
}

undergoing that kind of change might not consider labor costs as an important component of their competitiveness. A fourth possibility is that if investors see labor costs as a key component of their business strategy, they may locate production facilities in areas outside the EU, such as Eastern Europe and Southeast Asia, where labor costs are even lower than in the less-developed EU countries. Fifth, producers in the highcost countries may have preferred, thus far, to use the threat of social dumping as a bargaining chip with the unions in their home countries, rather than actually moving production.

Finally, even if employers in the moredeveloped countries are interested in pursuing low-wage, low-skill mass production in the less-developed countries, there still remains the question of whether the level of development in the less-developed countries, in things ranging from infrastructure and communications to education, is high enough to allow for any significant amount of foreign direct investment-that is, whether these countries have the capacity to increase their productivity dramatically. Table 9 gives the percentage of skilled and unskilled workers in industry in 10 of the EU countries, as reported by employers in 
a survey. Not surprisingly, the percentage of skilled workers is lowest in Portugal and Spain; surprisingly, however, it is not particularly low in Greece. In 1981, the illiteracy rate among those 15 years old and older was $7.1 \%$ in Spain, $9.5 \%$ in Greece, and $20.6 \%$ in Portugal. ${ }^{32}$ These results suggest that the level of development (in terms of skill, literacy, and infrastructure) in the least-developed EU countries could be so low as to provide a disincentive for foreign investment, at least until the Union's regional aid program begins to have a substantial impact on the development of these countries.

\section{Conclusions}

Our objective has been to evaluate the importance of unit labor costs-that is, worker compensation per unit of outputto the capital mobility aspect of the social dumping debate in the European Union. Our analysis shows that in 1986 there were sizable differences across EU countries in unit labor costs in manufacturing and that these differences did not narrow significantly over the 1980 s as the countries approached the single market-strongly suggesting that sizable differences exist today. Although we also found that during the 1980s the differences in compensation levels varied across industries within manufacturing, it is clear that, in general, the intercountry differences in productivity did not completely offset the inter-country differences in worker compensation, and consequently there appears to have been a labor cost incentive for capital mobility within the EU.

Yet, we also found that over the period 1980-88 investment flows to the member countries with lower unit labor costs were not remarkably larger than investment flows to the member countries with higher unit labor costs. Our findings, together with those of Flanagan (1993), thus pose the puzzle of why capital and labor flows have not yet responded strongly to the large

\footnotetext{
${ }^{32}$ Source: United Nations Statistical Yearbook. 1981 is the last year for which this measure is available.
}

Table 9. Percentage of Skilled and Unskilled Workers in Industry in the European Union, 1989. (Based on Employer Surveys)

\begin{tabular}{lcc}
\hline & \multicolumn{2}{c}{ Percentage of Employees Designated as: } \\
\cline { 2 - 3 } Country & Skilled & Unskilled \\
\hline Belgium & 60 & 40 \\
Denmark & - & - \\
France & 77 & 23 \\
Germany & 61 & 39 \\
Greece & 72 & 28 \\
Ireland & 61 & 39 \\
Italy & 91 & 9 \\
Luxembourg & - & 23 \\
Netherlands & 77 & 48 \\
Portugal & 52 & 46 \\
Spain & 54 & 36 \\
United Kingdom & 64 & \\
\hline
\end{tabular}

Source: EC ad hoc labor market survey (based on 25,000 industrial firms and carried out by the national institutes that conduct monthly EC business surveys), as reported in "Developments on the I abour Market in the Community," European Economy, No. 47, p. 65 .

differentials in unit labor costs and wages that persist within the EU. Flanagan suggested that internal EU migration failed to respond to the large wage differentials within the EU and to the lifting of previous barriers to labor mobility because "significant nonpecuniary migration costs (particularly those associated with language) appear to have overwhelmed the potential wage benefits from moving between EC member countries" (Flanagan 1993:184). We have suggested that capital may have failed to respond to the large unit labor cost differentials because of several factors, including barriers to capital mobility that have only recently been removed; uncertainty regarding the final terms of the Social Charter; the choice by employers in the higher-cost countries to pursue high-wage, high-skill, and high-value added production systems; the availability of even lowercost production sites outside the EU; and the low level of development in the lessdeveloped EU countries.

The policy implications of these findings depend on how one interprets the relative unresponsiveness of capital flows to labor 
cost differentials in the $\mathrm{EU}$ in recent years. On the one hand, it may be argued that capital will soon begin flowing at a much quicker pace to the lower-cost countries now that the barriers to the movement of capital and goods have been removed, and that the movement of capital will pick up even more once the uncertainty about the Social Charter has been completely resolved and, perhaps, once the regional aid program has significantly increased the level of development in the lower-cost countries. If one accepts that proposition, then the primary implication of this analysis is that the Union may have to pursue a policy of further upward harmonization of labor standards and perhaps even compensation costs in order to offset the current differentials. Of course, these actions would require a judgment on the part of the Union that the advantages of large capital flows to the lower labor cost countries (primarily the increase in employment and incomes in these countries) would be offset completely or in large part by the losses (primarily the loss of high-paying jobs in the wealthier countries).

Alternatively, the lack of large capital flows to the less-developed EU countries as of 1988 may be seen as an indication of future trends. The availability of even lower labor cost opportunities elsewhere in the world, in this view, or the adoption of highwage, high-skill production systems by employers in the more-developed countries, may continue to discourage capital movement within the EU. In that case, the implication is that further upward harmonization policies may not be necessary. Our findings therefore provide mixed signals on this important policy question. We have focused here on the labor cost incentive for capital mobility; a more comprehensive answer to the question of social dumping will have to take into account other factors in the investment location decision, such as education and skill levels, infrastructural development, land costs, transportation costs, and the particular costs of multinational operations.

\section{APPENDIX}

\section{DATA SOURCES}

Compensation cost data were obtained from an unpublished source used by the U.S. Department of Labor, Bureau of Labor Statistics: "Hourly Compensation Costs for Production Workers in Manufacturing, 33 Countries." Our output (or value added) data, used to calculate productivity and unit labor costs, are gross domestic products from the national accounts of the various countries, as reported in the OECD publication National Accounts 1977-1989, Detailed Tables, Volume II.

Our data on number of employees are taken from the National Accounts, and in a few cases (noted in the tables) from the ILO Yearbook of Labour Statistics. The hours worked per week are from the ILO Year$b o o k$, and the weeks of vacation and holidays per year are from the European Trade Union Institute's Collective Bargaining in Western Europe in 1989.

The purchasing power parity exchange rates and GDP expenditure weights are from the publication World Comparisons of Purchasing Power and Real Product for 1980 from Phase IV of the United Nations World Comparisons Project. PPP exchange rates for all of GDP are also available from the National Accounts; market exchange rates were obtained from the $\mathrm{Na}$ tional Accounts and the BLS.

Finally, we get some of our statistics, such as the index of real output per employee for all of the countries and GDP in manufacturing for Spain, from the World Bank World Tables; again, these cases are reported in the footnotes to the tables. 


\section{REFERENCES}

Addison, John, and W. Stanley Siebert. 1991. "The Social Charter of the European Community: Evolution and Controversies." Industrial and Labor Relations Review, Vol. 44, No. 4 (July), pp. 597-625.

1994. "Recent Developments in Social Policy in the New European Union." Industrial and Labor Relations Review, Vol. 48, No. 1 (October), pp. 5-27.

Agarwal, J. P. 1980. "Determinants of Foreign Direct Investment: A Survey." Weltwirtschsftliches Archiv, Vol. 116, pp. 739-73.

Cecchini, P. 1988. The European Challenge, 1992: The Benefits of a Single Market. Aldershot, U.K.: Wildwood House.

Commission of the European Communities. 1988. "Third Report from the Commission to the Council and Parliament on the Implementation of the Commission's White Paper on Completing the Internal Market." Com (88), 134 Final. Brussels, March 21:

Commission of the European Communities, Directorate-General for Economic and Financial Affairs. 1991. "Developments on the Labour Market in the Community: Results of a Survey Covering Employers and Employees." European Economy, No. 47, March, p. 65.

Cushman, David O. 1987. "The Effects of Real Wages and Labor Productivity on Foreign Direct Investment." Southern Economic Journal, Vol. 54, No. 1, pp. 174-85.

European Trade Union Institute. 1990. Collective Bargaining in Western Europe in 1989. Brussels.

Flanagan, Robert J. 1993. "European Wage Equalization Since the Treaty of Rome." In Lloyd Ulman, Barry Eichengreen, and William T. Dickens, eds., Labor and an Integrated Europe. Washington, D.C.: Brookings Institution, pp 167-87.

Froot, Kenneth A., and Jeremy C. Stein. 1991. "Exchange Rates and Foreign Direct Investment: An Imperfect Capital Markets Approach." Quarterly Journal of Economics, Vol. 106, No. 4, pp. 1191-1217. Hooper, Peter, and Kathryn A. Larin. 1989. "International Comparisons of Labor Costs in Manufacturing." Review of Income and Wealth, Series 35, No. 4 (December), pp. 335-55.

International Labour Office. Various years. Yearbook of Labour Statistics. Geneva: ILO.

Lange, Peter. 1992. "The Politics of the Social Dimension." In Alberta Sbragia, ed., Euro-politics: Institutions and Policymaking in the New European Community. Washington, D.C.: Brookings, pp. 225-56.

Leamer, Edward E. 1993. "Wage Effects of a U.S.Mexican Free Trade Agreement." In Peter M. Garber, ed., The Mexico-U.S. Free Trade Agreement.
Cambridge, Mass.: MIT Press, pp. 57-128.

Molle, Willem. 1990. The Economics of European Integration. Aldershot: Dartmouth.

Mosley, Hugh. 1990. "The Social Dimension of European Integration." International Labour Review, Vol. 129, No. 2, pp. 147-64.

Organization for Economic Cooperation and Development, Paris. 1991. National Accounts 1977-1989, Vols. 1 and 2.

Piore, Michael, and Charles Sabel. 1984. The Second Industrial Divide. New York: Basic Books.

Silvia, Stephen. 1991. "The Social Charter of the European Community: A Defeat for European Labor." Industrial and Labor Relations Review, Vol. 44, No. 4 (July), pp. 626-43.

Streeck, Wolfgang. 1991. "More Uncertainties: German Unions Facing 1992." Industrial Relations, Vol. 30, No. 3 (Fall), pp. 317-49.

Summers, Robert, and Alan Heston. 1988. "A New Set of International Comparisons of Real Product and Price Levels Estimates for 130 Countries, 19501985." Review of Income and Wealth, Series 34, No. 1 (March), pp. 335-55.

Turner, Lowell. 1993. "Prospect for Worker Participation in Management in the Single Market." In Lloyd Ulman, Barry Eichengreen, and William T. Dickens, eds., Labor and an Integrated Europe. Washington, D.C.: Brookings Institution, pp. 45-79.

Turvey, Ralph. 1990. "Labour Productivity." In Ralph Turvey, ed., Developments in International Labour Statistics. London: Pinter Publishers for ILO.

United Nations. 1993. World Investment Directory 1992: Developed Countries. New York: U.N.

United Nations. Comparison of the European Communities, 1987. World Comparisons of Purchasing Power and Real Product for 1980. New York: U.N.

United States Department of Labor, Bureau of Labor Statistics. Various years. "International Comparisons of Hourly Compensation Costs for Workers in Manufacturing." Washington, D.C.: Unpublished.

Van Mourick, Aad. 1989. "Countries; A Neoclassical Model of International Wage Differentials." In Molle, Willem, and Aad Van Mourick, eds., Wage Differentials in the European Community. Aldershot: Avebury.

World Bank. Various years. World Tables. Washington, D.C.

Zagardo, Janice Turtora. 1991. "Worldwide Convergence of Productivity Levels: Recent Empirical Evidence." Business Economics (October), Vol. 26, No. 4, pp. 19-25. 